How to cite: Șorea, I., Stoleriu, C.C., Ursu, A. (2019) Road Traffic Noise Modeling. Case Study: Vaslui Town, North-Eastern Romania. 2019 "Air and Water - Components of the Environment" Conference Proceedings, ClujNapoca, Romania, p. 375-384, DOI: 10.24193/AWC2019 37.

\title{
ROAD TRAFFIC NOISE MODELING. CASE STUDY: VASLUI TOWN, NORTH-EASTERN ROMANIA
}

\author{
Ionuț ȘOREA ${ }^{1}$, Cristian Constantin STOLERIU ${ }^{2}$, Adrian URSU ${ }^{3}$ \\ DOI: 10.24193/AWC2019 37
}

\begin{abstract}
In the last decades, the issue of environmental noise was highly debated as globalization and the automotive industry spread out. In Europe, the European Directive 2002/49/EC is at the moment the leading regulation directed to all Member States. It describes methods of assigning and modeling the environmental noise and sets as mandatory reporting the population size affected by the noise levels over the limit set by the national legislations. The current paper is concerned with the modeling of one of the main noise sources - road traffic. The methodology flow used in this study follows in terms of accuracy, complexity and cost of obtaining the data the current national legislation recommendations in the field of environmental noise management and evaluation (Government Decision no.321/2005). The study area is represented by the main streets crossing Vaslui town and a buffer of $50 \mathrm{~m}$ along of them, thus including the closest buildings to the road network. This area comprises a population of 9,858 inhabitants (9.87\% of the total urban population). The software used to map the road traffic noise was QGIS Brighton 2.6.1. (opeNoise plugin), having as main emission source the road network inside the study area and as attribute the number of vehicles together with some other quantitative and qualitative factors that might affect the sound power and its propagation. The data acquisition and the interim computation method used in the current paper are in accordance with the National Legislation. The final result is represented by the noise maps for the two most important noise indexes: $\mathrm{L}_{\text {den }}$ and $\mathrm{L}_{\text {night. }}$.
\end{abstract}

Keywords: Vaslui town, environmental noise, road traffic, GIS modeling, acoustic noise modeling

\section{INTRODUCTION}

The environmental noise is currently being studied for its high impact on citizens' life in the urban areas all over the world. The environmental noise comprises the railway, industrial, aircraft and road traffic noise. However, in the urban areas, the most important noise source is considered as being the road traffic (Murphy et al, 2016).

In order to reduce the road traffic generated noise, there are models being created using interim computation methods that take into consideration different

\footnotetext{
${ }^{1}$ Alexandru Ioan Cuza University of Iasi, Faculty of Geography and Geology (ionutsorea@yahoo.com)

${ }^{2}$ Alexandru Ioan Cuza University of Iasi, Faculty of Geography and Geology (cristoan@yahoo.com)

${ }^{3}$ Alexandru Ioan Cuza University of Iasi, Faculty of Geography and Geology
} 
ways of sound propagation, sound power of the emission source or sound frequency, all based on field measurements of traffic volume, speed etc. These models are being graphically presented as noise maps. Having depicted 5 decibels (A-weighted) (abbreviated as $\mathrm{dB}(\mathrm{A})$ ) noise level intervals on them, the noise maps are used by the local authorities to assess the population exposure. Thus they represent important tools in the decision making process.

At European level, the law that regulates the environmental noise problem is the Directive 2002/49/EC of the European Parliament and Council of 25 June 2002 relating to the assessment and management of environmental noise, directive that needs to be transposed into the local national legislations of each Member State of the European Union. For Romania, this means the Government Decision no. 321/2005 and further Ministerial Orders.

The current study is concerned with the road traffic noise modeling for the main streets within the boundaries of Vaslui town. This municipality is situated in the North-Eastern part of Romania, at the crossing point of parallel $46^{\circ} 39^{\prime}$ North and meridian $27^{\circ} 44^{\prime}$ East. The relief here is characterized by an average altitude of 200-300 $\mathrm{m}$ (Mocanu, 2008).

The road network being studied by the current paper is composed of Calugareni St. and Traian St. in the West, Stefan cel Mare St. in the Central part connected to Decebal St. in the North and Republicii Blvd. in the South, and Decebal St. and an extension of Stefan cel Mare St. in the East and South-East. The main road traffic on these streets comes from the National Roads (DN in Romanian) that are linked to Vaslui town's road network. These roads are the following: DN 15D (connection with Roman, Neamt county), DN 24 (connection with Barlad to the South and Iasi, Iasi county to the North) and DN 2F (connection with Bacau, Bacau county).

The actual study area (Fig. 1) is represented by a buffer of $50 \mathrm{~m}$ along the streets presented above. The reason behind this choice was pursuing a study that brings in a diverse road network, comprising streets that carry both light and heavy vehicles, noisesensitive institutions (i.e. schools), and an important percentage of the total population.

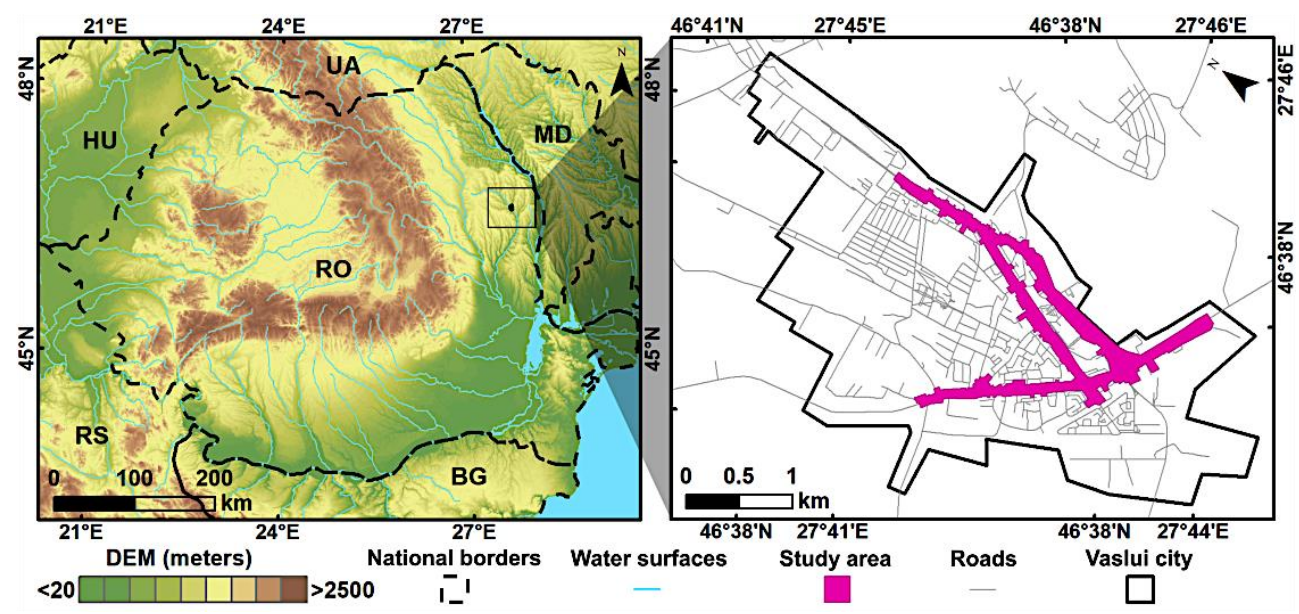

Fig. 1. Localization of the study area 
The study area has a total of 9,585 inhabitants $(9.87 \%$ of the total population of 97,067, according to the 2011 Population and Housing Census). The buffer dimension was chosen in order to include the buildings closest to the emission source and differentiate the buildings' façades (exposed and those opposite to the noise source).

For a better modeling of the road traffic noise, there are several factors taken into consideration. The climatic conditions can alter the noise propagation and hence should be included into the computation method. The general consensus is that lower the temperatures, higher the noise generated by vehicles (Subramani et al., 2012, Bendtsen et al., 2009, Mioduszewski et al., 2014). The noise level is also influenced by the relative humidity in the way that the traffic noise is higher when the humidity level is higher (Subramani et al., 2012).

Other factors that influence the road traffic noise levels are the vegetation and ground effects. The urban vegetation can absorb or reflect the noise, while the soil can absorb the noise function of its porosity (Yang, 2013). Nevertheless these factors were not included into the model due to the software used in this study.

It is to be noticed that neither traffic noise assessment, nor any kind of study was yet conducted on the road traffic of Vaslui town.

\section{DATA AND METHODS}

\subsection{Data used}

In order to model the environmental noise generated by road traffic in urban areas, there are two main layers to be used (Fig. 2).

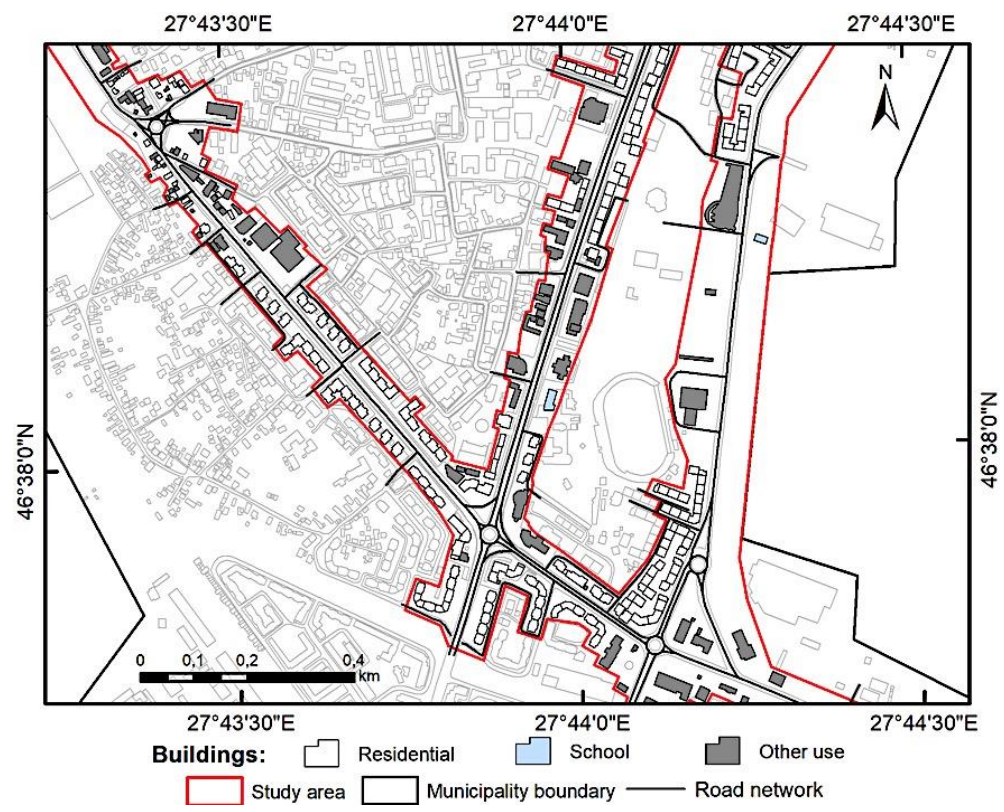

Fig. 2. Detail on the layers used in the traffic noise modeling (buildings and road network) 
The first one is that of the buildings being differentiated as residential, buildings having a special use that requires attention when studying the noise effects on population (schools and hospitals) and buildings with any other use (e.g. services, industry, state institutions). The buildings within the study area were digitized on the basis of an orthophotograph of Vaslui town.

The second layer is represented by the emission source of the traffic noise, the road network. The roads layer is of a polyline type. According to the Ministerial Order no. 1,830/2007, the roads with a width larger than $15 \mathrm{~m}$ were being digitized through two emission lines, one for each roadway. Any other road is represented by only one emission line. The digitization was also made based on an orthophotograph available on www.ancpi.ro website.

All these input data were further integrated into the opeNoise plugin, part of QGIS Brighton 2.6.1. open source software. This plugin is capable of generating noise levels for different distances away of the emission source considering buildings as obstacles in the way of noise propagation.

\subsection{Methods used}

The method used to model the traffic noise data for the study area follows entirely the National Legislation (Government Decision no. 321/2005 and further Ministerial Orders) and the Directive 2002/49/EC of the European Parliament and Council of 25 June 2002 relating to the assessment and management of environmental noise.

\subsubsection{Traffic data acquisition}

Traffic data was assigned to each emission line within the study area. The lines being situated at the edge of the study area were drawn quite a few meters outside the actual $50 \mathrm{~m}$ buffer along the main roads, so that the modeling will also take into consideration the effect of these lateral roads on the noise generation and propagation.

The road network was first of all divided into three main categories: main roads, connecting roads and roads within residential area. This division was made mainly due to the lack of traffic data.

The number of vehicles was obtained by field observations for two main roads, Traian St. and Stefan cel Mare St. (the sector between 'Crucea Garii' in the South and the junction with Decebal St. in the North). The other roads were assigned traffic data according to Tool 2.5 and Tool 4.5 of Ministerial Order no. $678 / 1344 / 915 / 1397 / 2006$. The number of vehicle was divided by time period, according to the same Ministerial Order, as shown in Table 1. A division was also made according to the vehicle types (light and heavy vehicles separated by the 3.5 tonne net load threshold).

For the vehicle speed, the values were assigned according to the National Legislation and not by actual measurements (Murphy et al., 2006). The longitudinal profiles (slope in opeNoise) were described as following: flat, down or up. The traffic flow type was assigned as being 'non-differentiated pulsed' for the entire road network. The road surface type was 'smooth' everywhere. 
Table 1. The timing of air and ground frost in autumn and spring across the Romanian Plain region (source: Ministerial Order no. 678/1344/915/1397/2006)

\begin{tabular}{|l|l|}
\hline Index & Time period \\
\hline $\mathrm{L}_{\text {day }}$ & $7 \mathrm{am}-7 \mathrm{pm}$ \\
\hline $\mathrm{L}_{\text {evening }}$ & $7 \mathrm{pm}-11 \mathrm{pm}$ \\
\hline $\mathrm{L}_{\text {night }}$ & $11 \mathrm{pm}-7 \mathrm{am}$ \\
\hline
\end{tabular}

\subsubsection{Data processing}

The two input layers were integrated into opeNoise together with a grid of points. The grid dimensions were $5 \mathrm{~m} \times 5 \mathrm{~m}$. The noise calculation plugin generates noise levels in $\mathrm{dB}$ (A-weighted) for every single point of the grid, according to the French national computation method 'NMPB-Routes-96 (SETRA-CERTU-LCPC-CSTB)', also described in the Directive 2002/49/EC. The result was defined by two main noise computation indexes: $\mathrm{L}_{\mathrm{den}}$ for the environmental noise assessment over a fullday time period and $\mathrm{L}_{\text {night }}$ to assess the noise during the $11 \mathrm{pm}-7$ am night period. The formula used to calculate $\mathrm{L}_{\mathrm{den}}$ is depicted as follows:

$$
\text { Lden }=10 \cdot \lg \frac{1}{24}\left(12 \cdot 10^{\frac{\text { Lday }}{10}}++4 \cdot 10^{\frac{\text { Levening }+5}{10}}+8 \cdot 10^{\frac{\text { Lnight }+10}{10}}\right),
$$

where

$\mathrm{L}_{\text {day }}, \mathrm{L}_{\text {evening }}$ and $\mathrm{L}_{\text {night }}$ represent the noise levels calculated accroding to NMPB-Routes-96 computation method for the time periods described in Table 1 .

The research ray for the current study was set to $50 \mathrm{~m}$, while the temperature mean was set to $25{ }^{\circ} \mathrm{C}$ and relative humidity to $50 \%$, according to the climatic conditions of the region (Larion, 2004).

\subsubsection{Noise data interpolation}

Even though the visual representation of noise levels is one of the most important steps in noise modeling, there is still a lack of a common opinion on the best noise data interpolation method (Murphy et al, 2006). In the same article, authors uses three different interpolation methods (Nearest Neighbour, Inverse Distance Weighting, Kriging), without choosing any of them as being an ultimate solution for data representation. Other articles that debated the idea of noise data interpolation are Farcaș and Sivertun, (2012) and Murat and Ebru, (2016).

The grid of points with the noise levels assigned for $\mathrm{L}_{\mathrm{den}}$ and $\mathrm{L}_{\text {night }}$ was then interpolated by using the Ordinary Kriging (OK) method with a stable semivariogram (Fig. 3), no anisotropy, normally distributed data and no trend within the noise levels data. Regarding the prediction errors, RMSE for $\mathrm{L}_{\text {den }}$ noise levels was 0.9 , while RMSE for $\mathrm{L}_{\text {night }}$ noise levels was 0.88 .

Once the interpolation finished, the symbology was assigned to the noise levels for the two indexes, with specific colors for the $5 \mathrm{~dB}(\mathrm{~A})$ intervals.

\section{RESULTS AND DISCUSSIONS}

The noise traffic modeling results in noise maps presenting the noise levels for $\mathrm{L}_{\text {den }}$ and $\mathrm{L}_{\text {night }}$ as $5 \mathrm{~dB}(\mathrm{~A})$ intervals, here delimited by contour lines. 


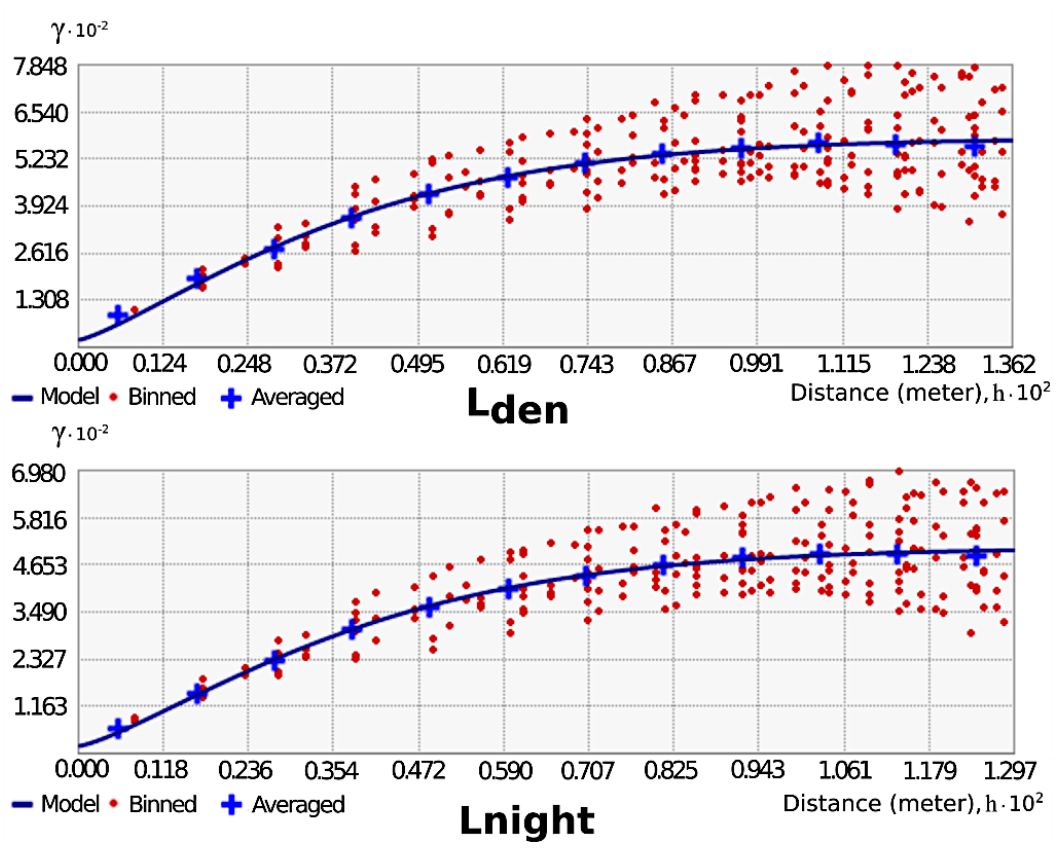

Fig. 3. $L_{d e n}$ and $L_{n i g h t}$ noise levels data semivariogram (ArcMap 10.2.2)

For the current study, the noise maps revealed the big influence that the National Roads coming from outside the urban area and the type of vehicles they carry have on the noise generation. The junctions of the main urban roads and their position inside the urban framework strongly influenced the final result as well.

For the $\mathrm{L}_{\mathrm{den}}$ index (Fig. 4), the street that generates the loudest traffic noise, meaning values higher than $75 \mathrm{~dB}(\mathrm{~A})$ distributed on its entire length, is Decebal St. Once this street meets Stefan cel Mare St. in the North of the study area, the 75-80 $\mathrm{dB}(\mathrm{A})$ noise interval widens on the both sides of the street. This can be explained by the high number of heavy vehicles Decebal St. carries.

The other streets within the study area face average noise levels between 65 $\mathrm{dB}(\mathrm{A})$ and $70 \mathrm{~dB}(\mathrm{~A})$. Among the six junction areas that have been included in the study area, the noise levels for $\mathrm{L}_{\mathrm{den}}$ index can even exceed $80 \mathrm{~dB}(\mathrm{~A})$. Thus, these junction areas must be taken into consideration when looking for solutions to decrease the environmental noise produced by cars.

By studying the traffic noise values distribution in the case of the $\mathrm{L}_{\text {night }}$ index (Fig. 5), one can notice they follow the same pattern as in the case of $L_{\text {den }}$ index, the difference lying in the $\mathrm{dB}(\mathrm{A})$ value itself. Thus, Decebal St. that carries the heavy traffic coming from the road traffic of National Roads DN 2 F and DN 24, and indirectly from DN 15D by a ring road in the southern part of the town (not included in the current study area), is characterized by $\mathrm{L}_{\text {night }}$ noise levels of $65-70 \mathrm{~dB}(\mathrm{~A})$.

The main streets inside the urban area (Traian St., Stefan cel Mare St., Republicii Blvd) have values of $L_{\text {night }}$ index of mainly $60-65 \mathrm{db}(\mathrm{A})$. The six junctions again have over the average values of $70 \mathrm{~dB}(\mathrm{~A})$ to $80 \mathrm{~dB}(\mathrm{~A})$. 


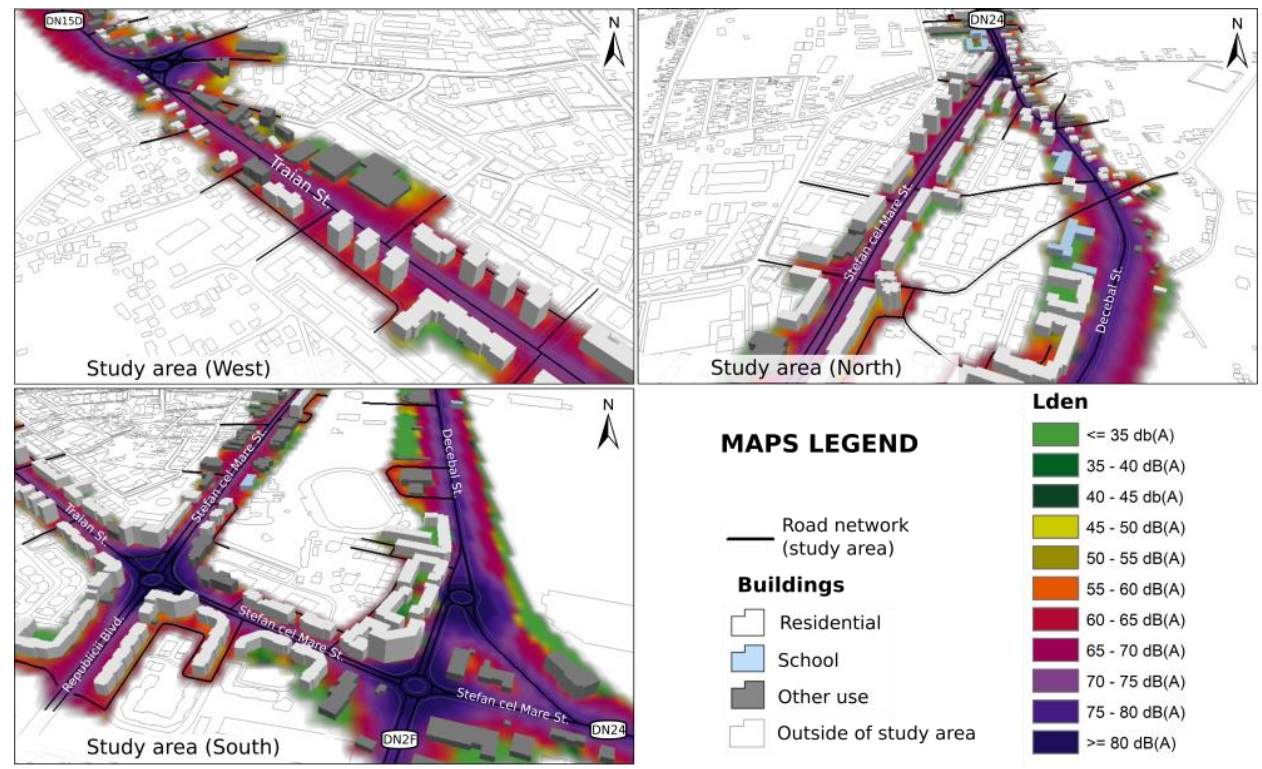

Fig. 4. Noise levels modeling for $L_{d e n}$ index in different parts of the study area

Inside the study area, there are no hospitals, but a number of seven educational institutions comprising three secondary schools, two high schools, one school gymnasium and one annex (Table 2).
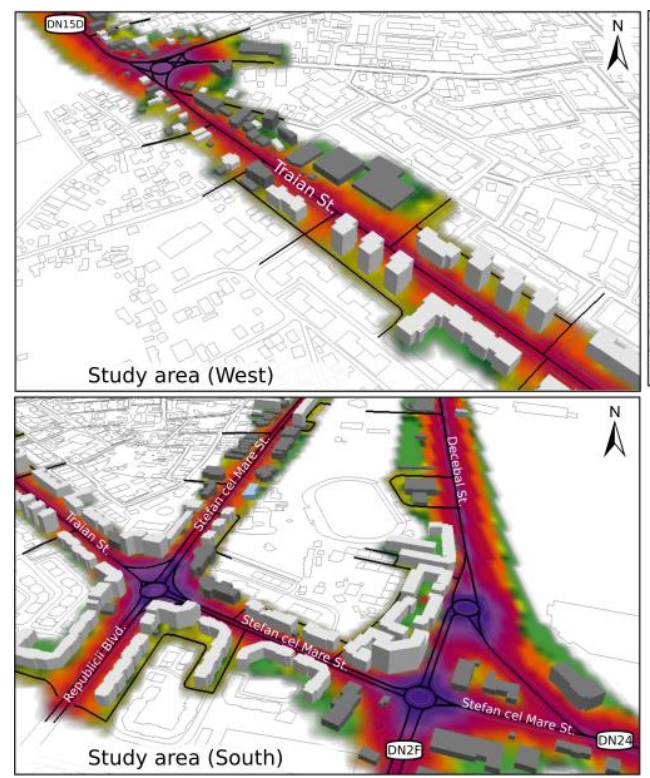

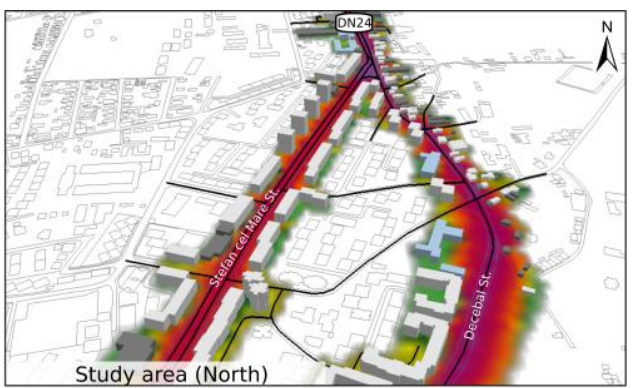

Study area (North)

MAPS LEGEND

Lnight

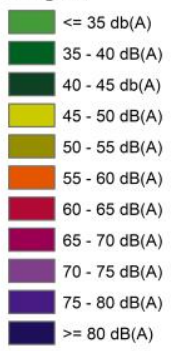

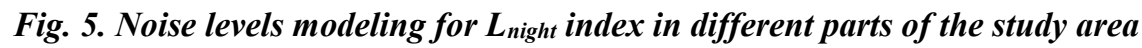

The activities held in these educational institutions can be highly disturbed by the traffic noise, causing among others the lack of concentration in the case of the students. 
The $\mathrm{L}_{\mathrm{den}}$ values are taken into consideration when finding solutions by authorities, the classes being held on daytime. The schools that present the highest $\mathrm{L}_{\text {den }}$ values are those situated close to Decebal St.

Table 2. Lden values for educational institutions within the study area

\begin{tabular}{|l|c|c|}
\hline \multicolumn{1}{|c|}{ Name } & Type & Lden \\
\hline $\begin{array}{l}\text { Școala Gimnazială nr. 2 "D. } \\
\text { Cantemir” }\end{array}$ & Secondary school & $40-70 \mathrm{~dB}(\mathrm{~A})$ \\
\hline $\begin{array}{l}\text { Școala Gimnazială nr. 6 “M. } \\
\text { Eminescu” }\end{array}$ & Secondary school & $45-65 \mathrm{~dB}(\mathrm{~A})$ \\
\hline $\begin{array}{l}\text { Școala Gimnazială nr. 7 “C-tin } \\
\text { Motaș” }\end{array}$ & Secondary school & $35-70 \mathrm{~dB}(\mathrm{~A})$ \\
\hline Liceul cu Program Sportiv Vaslui & High school & $35-70 \mathrm{~dB}(\mathrm{~A})$ \\
\hline Liceul Teoretic "Emil Racoviță” & High school & $35-65 \mathrm{~dB}(\mathrm{~A})$ \\
\hline $\begin{array}{l}\text { Sala de Sport a Liceului Teoretic } \\
\text { "Emil Racoviță” }\end{array}$ & Gymnasium & $35-70 \mathrm{~dB}(\mathrm{~A})$ \\
\hline $\begin{array}{l}\text { Anexă Liceul cu Program Sportiv } \\
\text { Vaslui }\end{array}$ & Annex & $35-75 \mathrm{~dB}(\mathrm{~A})$ \\
\hline
\end{tabular}

According to the Ministerial Order no. 152/558/532/2008, the limit value for $\mathrm{L}_{\mathrm{den}}$ is $70 \mathrm{~dB}(\mathrm{~A})$, while for $\mathrm{L}_{\text {night }}$ is $60 \mathrm{~dB}(\mathrm{~A})$. All the results presented above must be related to these limit values.

The importance of the noise maps lies in helping authorities to identify the areas where single-family houses and multi-family housing units are facing high noise levels, and thus searching for solutions in order to diminish the environmental noise generated by road traffic. The results obtained by different computation methods and by using licensed or open source software are accurate, being compatible with different formats of databases. Thus, they are highly used by the authorities concerned with the environmental noise assessment (Bilaşco et al, 2017).

In order for the results to be as conclusive as possible, the noise data should be subject to a validation process. Most of the time, this means taking measurements of the sound levels using specific tools (i.e. sound level meters) while counting the vehicles (Covaciu et al., 2015). Unfortunately, no validation was performed for the current study results.

\section{CONCLUSIONS}

The traffic noise modeling reveals the areas where the environmental noise values are high enough to disturb different aspects of citizens' lives. The interpretation of the noise maps is being conducted by comparing the values of the noise indexes and the limit values described by the National Legislation. Special attention is being given to residential buildings and institutions that are noisesensitive like educational and sanitary institutions. 
The current study revealed the influence that a heavy traffic has on the environmental noise values inside an urban area. The $L_{d e n}$ and $L_{\text {night }}$ values on the ring roads that carry almost entirely the heavy traffic of Vaslui town are, on average, $5 \mathrm{~dB}(\mathrm{~A})$ higher than those on the streets with similar light traffic volume, but no heavy vehicles. Another important topic whose influence on the noise levels was revealed through the current study is that of the junctions. The study area included six such elements of the local road network where the noise levels for $\mathrm{L}_{\text {den }}$ and $\mathrm{L}_{\text {night }}$ were higher with even $10 \mathrm{~dB}(\mathrm{~A})$ than area surrounding them. The results are only based on the NMPB-Routes-96 computation method as no validation through field measurements was performed.

For Vaslui town, the importance of the topic of the current study is high when thinking of this urban area, of almost 100,000 inhabitants, as not having noise maps generated for its road traffic yet. Thus the current study represents the beginning of the environmental noise assessment for this urban area.

The traffic noise modeling comes with limitations, mainly in the case of obtaining traffic data. A perfect model of traffic noise generation and propagation requires the number of vehicle per street and even a segment of a street, but practically this information is only possible if the authorities are collecting it. Another limitation derives from the software used for the current study, as it does not have the capability of integrating the vegetation and ground effects.

\section{REFERENCES}

1. Bendtsen, H., Lu, Q., Kohler, E. (2009), Temperature influence on road traffic noise, Californian OBSI measurement study, Report 169. Road Directorate, Danish Road Institute

2. Bilașco, Ș., Govor, C., Roșca, S., Vescan, I., Filip, S., Fodorean, I. (2017), GIS model for identifying urban areas vulnerable to noise pollution: case study. Front. Earth Sci. 2017, 11(2), 214-228. Higher Education Press and Springer-Verlag Berlin Heidelberg, DOI: 10.1007/s11707-017-0615-6.

3. Covaciu, D., Florea, D., Timar, J., Dima, D.S., Chiru, A. (2015). Study of the noise generated major road in a city. Annals of the Oradea University, Fascicle of Management and Technological Engineering, issue no.1

4. Farcaş, F., Sivertun, A. (2012). Road Traffic Noise: GIS Tools for Noise Mapping and a Case Study for Skane Region. The International Archives of the Photogrammetry, Remote Sensing and spatian Information Sciences, 34 (XXX)

5. Larion, D. (2004), Clima municipiului Vaslui, Ed. Terra Nostra, Iasi (in Romanian)

6. Mioduszewski, P., Taryma, S., Wozniak, R. (2014), Temperature influence on type/road noise of selected tyres. Inter-noise. Melbourne, Australia

7. Mocanu, A. (2008), Modul de utilizare a terenului și studiul calității solului în municipiul Vaslui. Ed. Universitatea Alexandru Ioan Cuza, Iasi. (in Romanian)

8. Murat, O., Ebru, S.E. (2016). Determination of traffic noise pollution of the city of Tekirdag. Journal of Environmental Protection and Ecology, 17(4), 1276-1284

9. Murphy, E., Rice, H., Meskell, C. (2006), Environmental noise prediction, noise mapping and GIS integration: the case of inner Dublin, Ireland. East-European 
Acoustical Association. 8th International Transport Noise and Vibration Symposium, St. Petersburg

10. Subramani, T., Kavitha, M., Sivaraj, K.P. (2012), Modeling of Traffic Noise Pollution. International Journal of Engineering Research and Applications, 2(3), 3175-3182

11. Yang, H.S. (2013), Outdoor noise control by natural/sustainable materials in urban areas. The University of Sheffield, School of Architecture ( $\mathrm{PhD}$ thesis)

12. *** (2002), Directive 2002/49/EC of the European Parliament and Council of 25 June 2002 relating to the assessment and management of environmental noise

13. *** (2005), Hotărârea de Guvern nr. 321 din 14.04.2005 (M.O. nr. 19/10.01.2008) privind evaluarea și gestionarea zgomotului ambiant, reactualizată prin Hotărârea de Guvern nr. 1260 (M.O. nr. 15/19.01.2013) (in Romanian)

14. $* * *$ (2006), Ordinul Ministrului M.M.G.A./M.T.C.T./M.S./M.A.I. nr. 678/1344/915/1397/2006 și publicat în Monitorul Oficial nr. 730/2006 pentru aprobarea „Ghidului privind metodele interimare de calcul al indicatorilor de zgomot pentru zgomotul produs de activitățile din zonele industriale, de traficul rutier, feroviar și aerian din vecinătatea aeroporturilor” (in Romanian)

15. *** (2007), Ordinul Ministrului nr. 1830/2007 pentru aprobarea „Ghidului privind realizarea, analizarea și evaluarea hărților strategice de zgomot” (in Romanian)

16. *** (2008), Ordinul Ministrului nr. 152/558/532/2008 pentru aprobarea „Ghidului privind adoptarea valorilor limită şi a modului de aplicare a acestora atunci când se elebaorează planurile de acțiune pentru indicatoii Lzsn și Lnoapte în cazul zgomotului produs de traficul rutier pe drumurile principale şi în aglomerări, traficul feroviar pe căile ferate principale şi în aglomerări, traficul aerian pe aeroporturile mari şi/sau urbane şi pentru zgomotul produs în zonele de aglomerări unde se desfaşoară activităţi industriale prevazute în anexa nr. 1 la O.U.G nr. $152 / 2005$ privind prevenirea și controlul integrat al poluării” aprobată cu modificări și completări prin Legea nr. 84/2006 (in Romanian)

17. *** (2011) Population Census (Recensământul populației și al locuințelor), Institutul Naţional de Statistică, București (in Romanian) 